\title{
Office of Administrative Management
}

National Cancer Institute

\section{Source}

National Cancer Institute. Office of Administrative Management. NCI Thesaurus. Code C18612.

The Office of Administrative Management, develops and executes the administrative, fiscal, and management aspects of (institute) programs. The Office of Administrative Management plans and directs the day-to-day administrative functions of (the institute) through the following sections: administrative management; financial management; grants and contracts management; and personnel management. (from NHGRI: Mission Statement and Organization October 1995) 